Vol 12, Issue 1, 2019

\title{
IN VITRO ANALYSIS: THE ANTIMICROBIAL AND ANTIOXIDANT ACTIVITY OF ZINC OXIDE NANOPARTICLES FROM CURCUMA LONGA
}

\author{
VINOY JACOB, RAJIV P* \\ Department of Biotechnology, Karpagam Academy of Higher Education, Eachanari, Coimbatore, Tamil Nadu, India. \\ Email: rajivsmart15@gmail.com
}

Received: 03 August 2018, Revised and Accepted: 14 September 2018

\section{ABSTRACT}

Objective: Curcuma longa is a known natural medicine for inflammation from ancient times. It has a low absorption rate and poor solubility. Hence, it is used for the green synthesis of nanoparticles. Zinc oxide nanoparticle (ZnO NPs) is famous nanoparticles which are economical, less toxic, and brilliantly biocompatible. They have potential biomedical properties, mainly anticancer, antidiabetic, and antimicrobial.

Methods: The present study was designed to investigate in vitro analysis of the antimicrobial activity against pathogenic bacteria and fungi and its ability to scavenge reactive oxygen radicals of ZnO NPs.

Results and Conclusion: The results indicated that ZnO NPs produced from $C$. longa had higher antimicrobial activity against Escherichia coli, Staphylococcus aureus, Streptococcus pyogenes, and Candida albicans. Therefore, we suggest that ZnO NPs can be used as the antimicrobial agent. It is a good scavenger of superoxide radical, nitric oxide, and hydrogen peroxide and has reducing power, which is greater than ascorbic acid at a higher concentration.

Key words: Green synthesis, Zinc oxide nanoparticles, Rhizome, Curcuma longa, Antibacterial, Antifungal, Antioxidant.

(C) 2019 The Authors. Published by Innovare Academic Sciences Pvt Ltd. This is an open access article under the CC BY license (http://creativecommons. org/licenses/by/4. 0/) DOI: http://dx.doi.org/10.22159/ajpcr.2019.v12i1.28808

\section{INTRODUCTION}

Nanotechnology represents innovation and facilitates the platform to fabricate novel nanomaterials for a wide range of biological and biomedical applications [1]. Biosynthesis or green synthesis of nanoparticles/nanomaterials is becoming increasingly popular as safer, cost-effective, easy to use, timesaving, free from toxics and pollutants, and simple without many environmental concerns. It is an alternative to the usual physical and chemical process [2,3]. Therapeutic nanomaterials for biomedical and pharmaceutical applications are being carried out by different green synthesis technologies using macro- and micro-scopic organisms (bacteria, fungi, microalgae, seaweeds, and plants) [4]

A zinc oxide nanoparticle ( $\mathrm{ZnO} \mathrm{NP}$ ) has created a great interest due to its large bandwidth and high excitation binding energy. It possesses potential biological applications such as antimicrobial (bacterial and fungal), antioxidant, anticancer, wound healing, antiinflammatory, and antidiabetic [5]. ZnO NP offers simple and easy fabrication and is considered biosafe and biocompatible making them ideal for biomedical applications such as biomolecular detection, nanodiagnostics, nanomedicine, luminescence, and photocatalytic photodiode response [6].

Antibacterial and antifungal activity of ZnO NPs against various pathogenic microbes among humans and plants (bacteria and fungi) such as Bacillus subtilis, Salmonella sp., Staphylococcus aureus, Escherichia coli, Aspergillus flavus, and Aspergillus niger using well diffusion method has been reported by various researchers $[7,8]$. Some researchers have investigated the antioxidant activity of green synthesized ZnO NP from Ceropegia candelabrum L. [9], Polygala tenuifolia [10], Cassia fistula [11], and Eucalyptus globules [12]. Curcuma longa is a medicinal plant abundantly available in South India. C. longa (turmeric) has curcumin which is a polyphenolic pigment. It is often used as traditional medicine with a wide range of potent medicinal activities for the treatment of inflammation, asthma, wounds, and Alzheimer disease [13]. ZnO NPs were produced through Zn (II) complex formation using C. longa extract as reducing agent [14]. Raghad et al. [15] demonstrated the green synthesis of titanium dioxide NPs ( $\mathrm{TiO}_{2}$ NPs) from the aqueous extract of $C$. longa and their biological activities. Extracts of $C$. longa have been used for the synthesis of silver nanoparticles by the simple method of green synthesis [16].

The purpose of this investigation was to develop the biogenic zinc oxide nanoparticles from $C$. longa extract as stabilizing and reducing agent and an analysis of their antibacterial, antifungal and antioxidant activity at in vitro level.

\section{METHODS}

In this investigation, all chemicals and reagents were obtained from Sigma, Aldrich. Zinc oxide nanoparticles were synthesized from $C$. longa rhizome by an eco-friendly method which was characterized using X-ray diffraction and transmission electron microscopy. Healthy and fresh C. longa rhizomes were collected from the local market, Coimbatore. C. longa rhizomes were verified and authenticated by the Botanical Survey of India, Coimbatore, Tamil Nadu, India, and the voucher specimen was deposited for future reference at the same institute.

\section{Antibacterial activity}

An analysis of antibacterial activity was done following agar well diffusion method according to Rajasekar et al. [17] incorporating a few modifications. Gram-positive organisms (Staphylococcus aureus and Streptococcus pyogenes) and Gram-negative organisms (E. coli, Salmonella typhi, and Klebsiella pneumonia) were used in this investigation. The media were prepared using nutrient agar, and $100 \mu \mathrm{l}$ of overnight pure culture of the pathogenic organism $\left(10^{4} \mathrm{cells} / \mathrm{ml}\right)$ was spread on the plates. Five wells $(5 \mathrm{~mm}$ ) were made in each plate after a few minutes. Different concentrations of ZnO NPs (25-100 $\mu \mathrm{g} / \mathrm{ml})$ were poured into each well. Tetracycline having $/ \mathrm{ml}$ was loaded in one well, and it was used as a control during the experiment. The plates were then kept for incubation at $37^{\circ} \mathrm{C}$ for a period of $24 \mathrm{~h}$. The zone of inhibition was obtained by measuring the diameter in millimeters. 


\section{Antifungal activity}

An analysis of antifungal activity was carried out by well diffusion method according to Magaldi et al. [18]. The fungal pathogens such as A. niger, Aspergillus oryzae, and Candida albicans were used in this assay. Potato dextrose agar (PDA) media were prepared and poured in the plates. Fungal pathogens were inoculated carefully after the solidification of PDA. Five wells ( $5 \mathrm{~mm}$ of size) were cut out on the agar plates. Various concentration of ZnO NP $(25-100 \mu \mathrm{g} / \mathrm{ml})$ and antifungal agent (positive control) ketoconazole $(20 \mu \mathrm{g} / \mathrm{ml})$ was introduced in well. The plates were incubated for 2-3 days at room temperature. After 3 days, the zone of inhibition was obtained measured in millimeter.

\section{Analysis of antioxidant activity}

\section{1,1-diphenyl-2-picrylhydrazyl (DPPH) radical scavenging assay}

DPPH radical scavenging activity was analyzed following the method of Malterud et al. [19]. Varied concentrations $(50-1000 \mu \mathrm{g} / \mathrm{ml})$ of $\mathrm{ZnO} \mathrm{NP}$ and ascorbic were prepared. $2.96 \mathrm{ml}$ of $0.1 \mathrm{mM} \mathrm{DPPH}$ solution was added to $3 \mathrm{ml}$ of the prepared solutions. The mixture was stirred thoroughly and was kept in the dark room for 20 min to incubate. Shimadzu UV-2450 spectrophotometer was used to read the absorbance of the reaction mixture at $517 \mathrm{~nm}$. Ascorbic acid was used as a standard solution while $0.1 \mathrm{mM} \mathrm{DPPH}$ was used as a control.

\section{Hydrogen peroxide assay}

An assay of hydrogen peroxide was performed following the method of Gocer et al. [20]. $1 \mathrm{ml}$ of $\mathrm{ZnO} \mathrm{NP}(50-1000 \mu \mathrm{g} / \mathrm{ml})$ and standard ascorbic acid were mixed with $0.6 \mathrm{ml}, 50 \mathrm{mM}$ hydrogen peroxide (phosphate buffer, $\mathrm{pH}$ 7.4). The mixture was incubated at room temperature for $10 \mathrm{~min}$. Absorbance was detected by Shimadzu UV2450 spectrophotometer at $230 \mathrm{~nm}$.

\section{Reducing power assay}

$\mathrm{An}$ analysis of the reducing power of green synthesized $\mathrm{ZnO} \mathrm{NP}$ was obtained using the method of Oyaizu's [21]. Varied concentration $(50-1000 \mu \mathrm{g} / \mathrm{ml})$ of $1 \mathrm{ml} \mathrm{ZnO} \mathrm{NP}$ and ascorbic acid was added together with $2.5 \mathrm{ml}$ of $200 \mathrm{mM}$ phosphate buffer (pH 6.6) and $2.5 \mathrm{ml}$ of $1 \%$ potassium ferricyanide. The mixture was kept for incubation at $50^{\circ} \mathrm{C}$ for $20 \mathrm{~min}$ and allowed to cool rapidly. $10 \%$ of $2.5 \mathrm{ml}$ trichloroacetic acid was added for $10 \mathrm{~min}$. The mixture was centrifuged at $3000 \mathrm{rpm}$ for $10 \mathrm{~min}$. The supernatant was obtained and added to $2.5 \mathrm{ml}$ of deionized water and $1 \mathrm{ml}$ of ferric chloride $(0.1 \%)$. The absorbance of the mixture was detected using Shimadzu UV-2450 spectrophotometer at $700 \mathrm{~nm}$.

\section{Nitric oxide scavenging activity}

Sodium nitroprusside was used for the nitric oxide generation of Griess reaction using the spectrophotometric method [22]. $100 \mu \mathrm{l}$ of sodium nitroprusside (5 mM and $\mathrm{pH} 7.4$ ) was added to $100 \mu \mathrm{l}$ varied concentrations of ZnO NP and ascorbic acid (50-1000 $\mu \mathrm{g} / \mathrm{ml})$. The mixture was incubated at $25^{\circ} \mathrm{C}$ for $30 \mathrm{~min}$. The preparation of control was made without test nanoparticles. $1.5 \mathrm{ml}$ of the incubated solution was diluted with $1.5 \mathrm{ml}$ Griess reagent $(2 \%$ phosphoric acid, $1 \%$ sulfanilamide, and $0.1 \% \mathrm{~N}$-1-naphthylethlene di-amine dihydrochloride). The absorbance of the mixture was measured using Shimadzu UV-2450 spectrophotometer.

\section{superoxide radical scavenging assay}

The scavenging activity of superoxide radical was analyzed by the nitroblue tetrazolium reduction assay following the method [23]. $1 \mathrm{ml}$ nitroblue tetrazolium solution (1 M NBT in $100 \mathrm{mM}$ phosphate buffer, $\mathrm{pH}$ 7.4), NADH solution (1 M NADH in $100 \mathrm{mM}$ phosphate buffer, $\mathrm{pH}$ 7.4) $1 \mathrm{ml}$ of the varied concentration of samples (ZnO NP and ascorbic acid), and $0.1 \mathrm{ml}$ of $50 \mathrm{mM}$ phosphate buffer were added. $100 \mu \mathrm{l}$ phenazine methosulfate solutions were also added. The absorbance of the mixture was measured using Shimadzu UV-2450 spectrophotometer at $530 \mathrm{~nm}$.

\section{Statistical analysis}

Three independent tests performed under the same experimental condition were used to obtain the results as a mean \pm standard deviation.

\section{RESULTS AND DISCUSSION}

\section{Characterization of zinc oxide nanoparticles}

The synthesized zinc oxide nanoparticles are spherical in shape with an average size of $25 \mathrm{~nm}$ (Figs. 1 and 2).

\section{Antibacterial activity}

Fig. 3 shows the antibacterial activity of the synthesized ZnO NP against pathogenic bacteria. At a different concentration of samples, the distinct zone of inhibition was formed around the wells. Tetracycline used as a control to compare the zones. Significant results were observed in E. coli, S. aureus, and K. pneumonia. S. typhi and S. aureus showed less inhibition. Maximum zone of inhibition was observed in E. coli at a higher concentration $(100 \mu \mathrm{g} / \mathrm{ml})$ when compared to others. Minimum zone of inhibition was observed in S. typhi at $25 \mu \mathrm{g} / \mathrm{ml}$ concentration. E. coli and $S$. aureus showed a higher zone of inhibition than tetracycline (control). This result indicates that ZnO NP can be used as an antibacterial agent. $\mathrm{ZnONP}$ is a less toxic and low-cost nanoparticle that can be used in many fields that include antibacterial, antifungal, antioxidant, and anticancer ones $[24,25]$. The antibacterial activity of $\mathrm{ZnO} \mathrm{NP}$ was dependent on their capability to activate excess ROS generation such as superoxide anion, hydrogen peroxide, and hydroxyl radical generation [26].ZnO NP antibacterial activity may associate with the accretion in bacterial cells cytoplasm and promote the release of $\mathrm{Zn}^{2+}$. It leads to the fragmentation of bacterial cell membrane, damage in membrane protein and genomic weakness resulting in the death of bacteria [27-29].

\section{Antifungal activity}

Fig. 4 shows the antifungal activity of ZnO NP against the chosen pathogenic fungus. Agar well diffusion method was used for this study. In different concentration of zinc oxide, nanoparticles showed efficient antifungal activity for $C$. albicans and $A$. oryzae than A. niger.

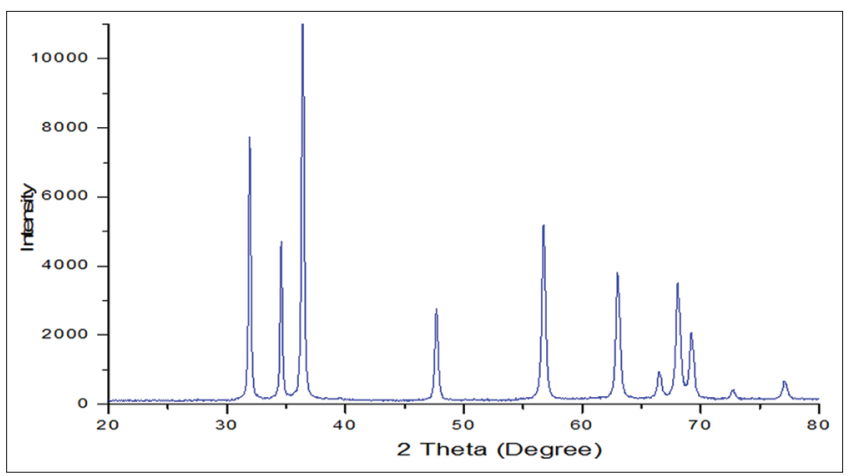

Fig. 1: X-ray powder diffraction spectra of Curcuma longa rhizomes mediated zinc oxide nanoparticles

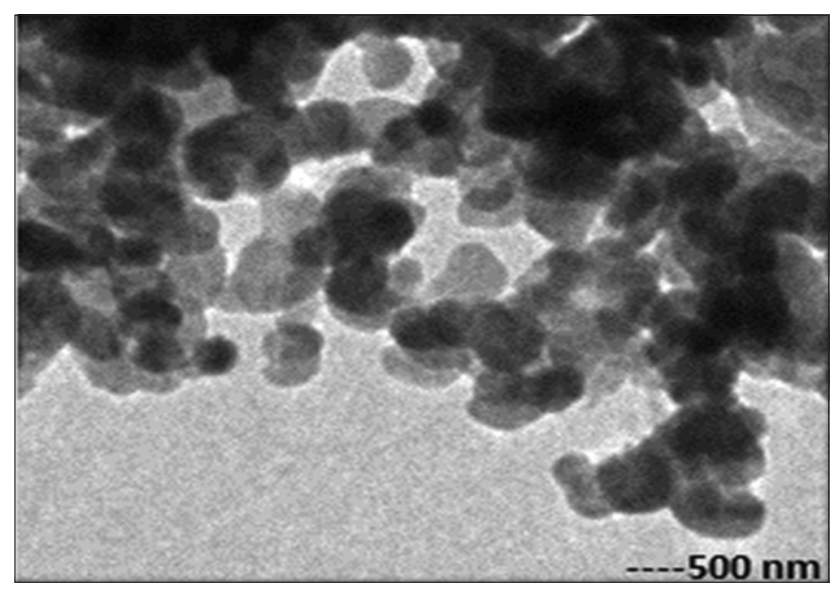

Fig. 2: Transmission electron microscopy images of Curcuma longa rhizomes mediated zinc oxide nanoparticles 


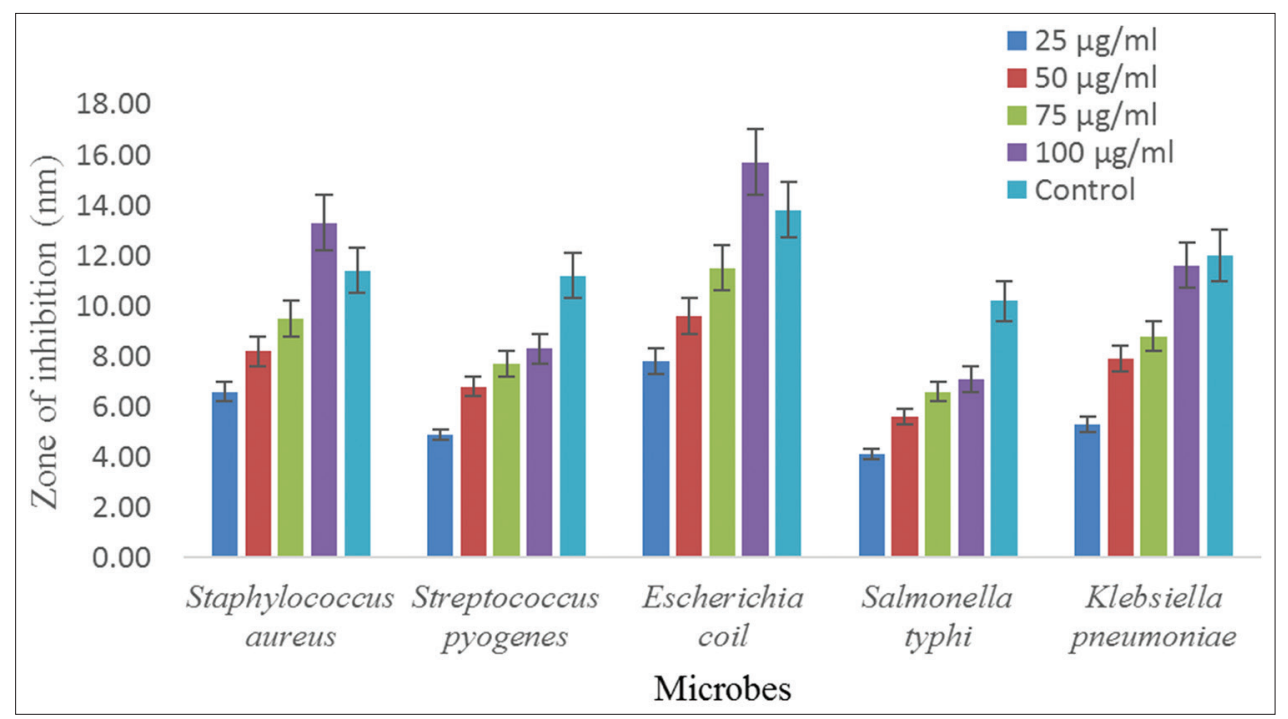

Fig. 3: Antibacterial activity of Curcuma longa mediated zinc oxide nanoparticles. Data represent mean \pm standard error

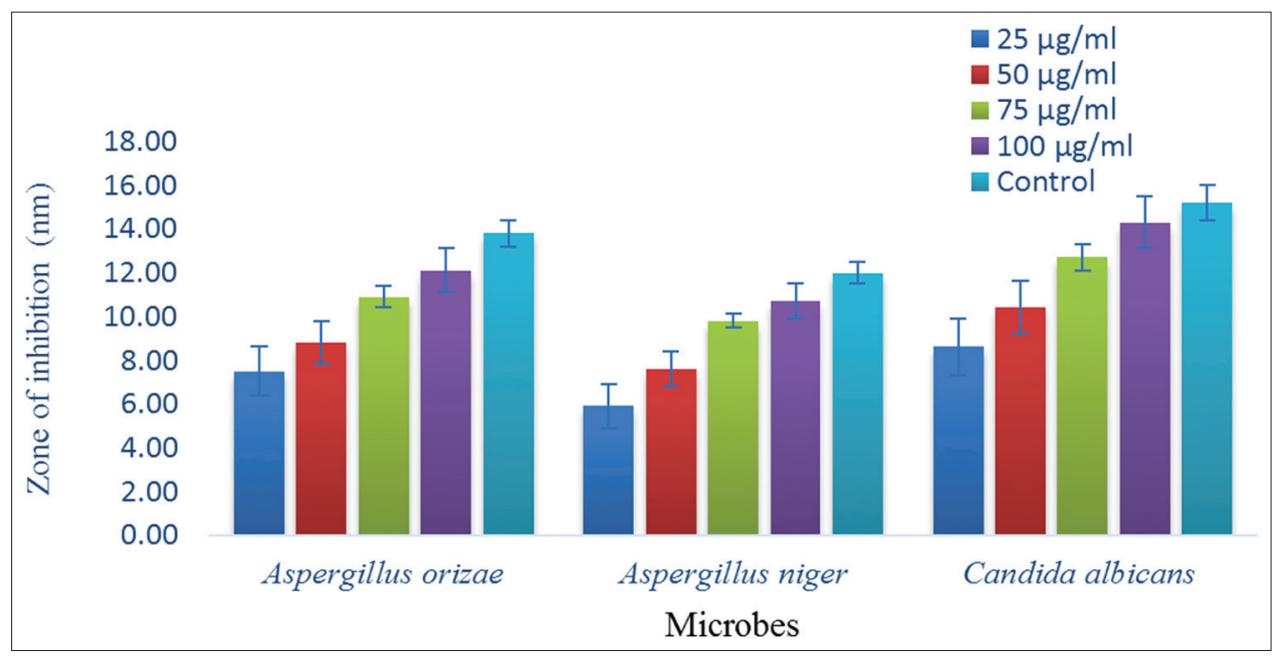

Fig. 4: Antifungal activity of Curcuma longa mediated zinc oxide nanoparticles. Data represent mean \pm standard error

At $100 \mu \mathrm{g} / \mathrm{ml}$ concentration, C. albicans showed the highest zone of inhibition, which was higher than control. The lowest inhibition was observed at $25 \mu \mathrm{g} / \mathrm{ml}$ concentration against $A$. niger. Some commercial antifungal agents create side effects [30,31]. This problem leads to the development of a natural antifungal agent [32]. This study suggests that $\mathrm{ZnO} \mathrm{NP}$ can be the best naturally available antifungal agent.

\section{Antioxidant activity}

Fig. 5 shows DPPH radical scavenging activity of ZnO NP. By getting hydrogen or electron from donor atom 1,1- diphenyl-2- picrylhydrazyl free radical is reduced [33]. The odd electron of DPPH accepts the hydrogen atom from the antioxidants and changes to identical hydrazine [34]. DPPH is an easy and fast way to evaluate antioxidant property using spectrophotometer [35]. According to the dose, the radical scavenging activity of $\mathrm{ZnO} \mathrm{NP}$ was increased. A significant result was observed at $200 \mu \mathrm{g} / \mathrm{ml}$, which is a bit less than ascorbic acid. Similar result revealed that nanoparticles could increase the antioxidant property [36]. Lipid peroxidation and cyclooxygenase activity were inhibited by curcumin, which had higher antioxidant activity [37].

Zn0 NP hydroxyl radical scavenging activity is shown in Fig. 6. The ZnO NP activity was increased based on the concentration. Higher activity was observed at $\mathrm{IC}_{200}-200 \mu \mathrm{g} / \mathrm{ml}$ of $\mathrm{ZnO} \mathrm{NP}$ than ascorbic acid. The maximum level of hydrogen peroxide caused oxidation in

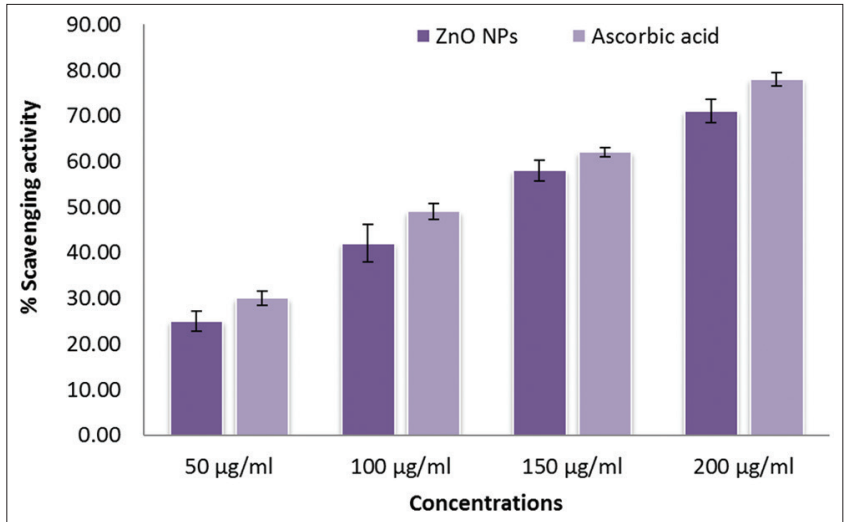

Fig. 5: 1,1-diphenyl-2-picryl hydrazyl scavenging activity of Curcuma longa mediated zinc oxide nanoparticles. Data represent mean \pm standard error

protein, nucleic acid, and lipids of cells which led to mutagenesis and lethal condition to cells. The cells could be protected by removing $\mathrm{H}_{2} \mathrm{O}_{2}$ using catalase [38]. Naturally synthesized $\mathrm{ZnO} \mathrm{NP}$ was good hydroxyl radical scavengers. Phenolic was an essential compound for antioxidant property [39] that was present in ZnO NP. 


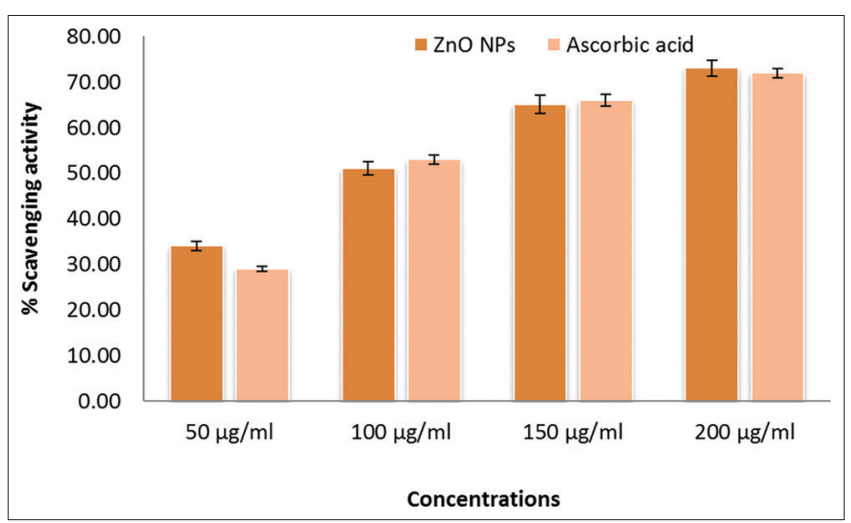

Fig. 6: Hydrogen peroxide scavenging activity of Curcuma longa mediated Zinc oxide nanoparticles. Data represent mean \pm standard error

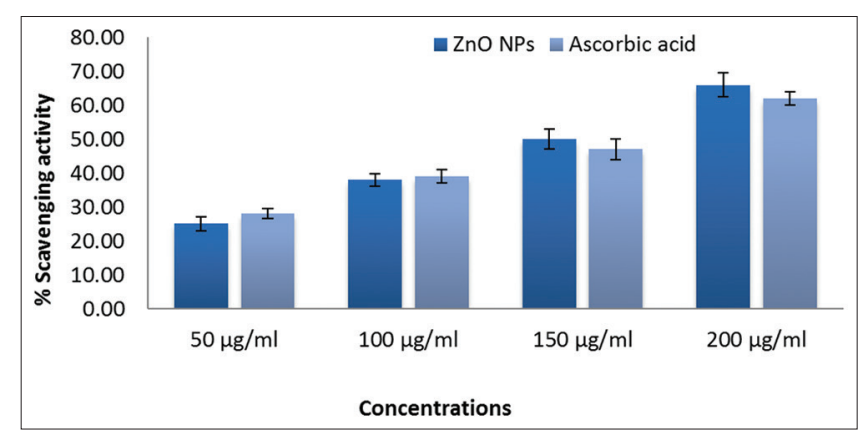

Fig. 7: Reducing power assay of Curcuma longa mediated zinc oxide nanoparticles. Data represent mean \pm standard error

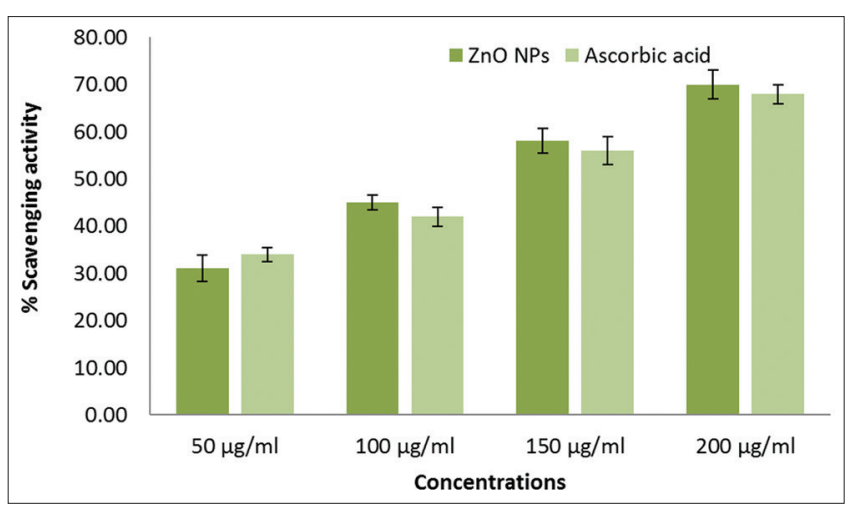

Fig. 8: Nitric oxide scavenging activity of Curcuma longa mediated zinc oxide nanoparticles. Data represent mean \pm standard error

The reducing power of a compound (Fig. 7) is linked to the antioxidant activity [40]. The reducing power of zinc oxide nanoparticles increased in a dose-dependent manner. The value ZnO NP was $200 \mu \mathrm{g} / \mathrm{ml}$, and it showed nearly the same efficacy as the standard ascorbic acid. This implied that ZnO NP had significant ability to react with free radicals to make them stable. The scavenging activity (Fig. 8) of nitric oxide was determined by the ability to inhibit the formation of nitrite by direct competition with oxygen and oxides [41]. ZnO NP showed more nitric oxide scavenging activity of $200 \mu \mathrm{g} /$ $\mathrm{ml}$ compared to ascorbic acid. Superoxide radical scavenging ability (Fig. 9) was determined by spectrophotometer. ZnO NP showed increased scavenging activity of $200 \mu \mathrm{g} / \mathrm{ml}$ compared to ascorbic acid. Superoxides were dangerous to the body cell as they had the ability to oxidize DNA and protein [41].

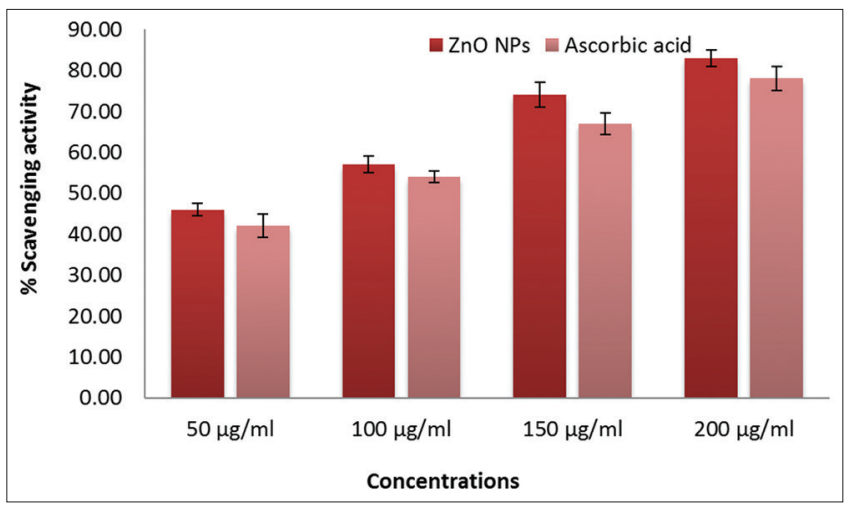

Fig. 9: Superoxide radical scavenging activity of Curcuma longa mediated zinc oxide nanoparticles. Data represent mean \pm standard error

\section{CONCLUSION}

It can be concluded that ZnO NP synthesized from $C$. longa possesses strong antibacterial, antifungal, and antioxidant activity based on the above in vitro analysis. In higher concentrations, it has significant antimicrobial activity against pathogenic bacteria and fungi. It is also a good source of antioxidant property.

\section{AUTHOR'S CONTRIBUTIONS}

All authors contributed equally to this manuscript.

\section{CONFLICTS OF INTEREST}

No conflicts of interest.

\section{REFERENCES}

1. Zhao J, Castranova V. Toxicology of nanomaterials used in nanomedicine. J Toxicol Environ Health B Crit Rev 2011;14:593-632.

2. Jayanta S, Avik M, Santhos K. A novel green synthesis of silver nanoparticles and their catalytic action in reduction of methylene blue dye. Sust Environ Res 2017;27:245-50.

3. Sunita P, Rajeshwari S, Rajiv P, Rajendran V, Seenivasan R. Green synthesis of silver nanoparticle from leaf extract of Aegle marmelos and evaluation of its antibacterial activity. Int J Pharm Pharm Sci 2015;7:169-73.

4. Kuppusamy P, Yusoff MM, Maniam GP, Govindan N. Biosynthesis of metallic nanoparticles using plant derivatives and their new avenues in pharmacological applications - An updated report. Saudi Pharm J 2016;24:473-84.

5. Agarwal H, Kumar SV, Rajeshkumar S. A review on green synthesis of zinc oxide nanoparticles - An eco-friendly approach. Res Eff Tech 2017;3:406-13.

6. Jamdagni P, Khatri P, Rana JS. Green synthesis of zinc oxide nanoparticles using flower extract of nyctanthes arbor-tristis and their antifungal activity. J King Saud Univ 2018;30:168-75.

7. Rajiv P, Rajeshwari S, Venckatesh R. Bio-fabrication of zinc oxide nanoparticles using leaf extract of Parthenium hysterophorus L. And its size-dependent antifungal activity against plant fungal pathogens. Spectrochim Acta A Mol Biomol Spectrosc 2013;112:384-7.

8. Narendhran S, Rajiv P, Rajeshwari S. Influence of zinc oxide nanoparticles on growth of Sesamum Indicum L. In zinc deficient soil. Int J Pharm Pharm Sci 2016;8:365-71.

9. Murali $\mathrm{M}$, et al. Antibacterial and antioxidant properties of biosynthesized zinc oxide nanoparticles from Ceropegia candelabrum L. An endemic species. Spectrochim Acta A Mol Biomol Spectrosc 2017;15:104-9.

10. Nagajyothi PC, Sang Ju, Yang IJ, Sreekanth TV, Kim KJ, Shin HM. Antioxidant and anti-inflammatory activities of zinc oxide nanoparticles synthesized using Polygala tenuifolia root extract. J Photochem Photobiol B 2015;146:10-7.

11. Suresha D, Nethravathi PC, Udayabhanu CG, Rajanaik H, 
Nagabhushana H, Sharma SC. Green synthesis of multifunctional zinc oxide $(\mathrm{ZnO})$ nanoparticles using Cassia fistula plant extract and their photodegradative, antioxidant and antibacterial activities. Mat Sci Semicon Proc 2015;3:446-54.

12. Balaji S, Kumar MB. Facile green synthesis of zinc oxide nanoparticles by Eucalyptus globulus and their photocatalytic and antioxidant activity. Adv Powder Technol 2017;28:785-97.

13. Sawant VJ, Bamane SR, Pachchapurkar SM. Chitosan encapsulated curcumin loaded zinc ferrite core shell nanoassembly for biocompatible drug delivery on chicken embryonic stem cells. Der Chemica Sinica 2013;4:67-78.

14. Fatimah I, Septian PY, Lintang MN. Green Synthesis of $\mathrm{ZnO}$ Nanoparticles via Complex Formation by using Curcuma longa extract. AIP Conference Proceedings 2016

15. Raghad DH, Abdul J, Rasha S, Ahmed N, Abd N. Biological synthesis of titanium dioxide nanoparticles by Curcuma longa plant extract and study its biological properties. WSN 2016;49:204-22.

16. Shameli K, Ahmad MB, Zamanian A, Sangpour P, Shabanzadeh P, Abdollahi Y, et al. Green biosynthesis of silver nanoparticles using curcuma longa tuber powder. Int J Nanomedicine 2012;7:5603-10.

17. Rajasekar P, Priyardharshini S, Rajarajeshwari T, Shivashri C. Bio-inspired synthesis of silver nanoparticles using Andrographis paniculata whole plant extract and their anti-microbial activity over pathogenic microbes. Int J Res Biomed Biotech 2013;3:4752-61.

18. Magaldi S, Mata S, Hartung C. In vitro susceptibility to fluconazole of Candida spp. isolates comparing three different methods. J Mycol Med 2001;11:123-6.

19. Malterud KE, Farbrot TL, Huse AE, Sund RB. Antioxidant and radical scavenging effects of anthroquinones and anthrones. Pharmacological 1993;47:77-85.

20. Gocer HY, Menzek A, Gulcin I. Synthesis and antioxidantproperties of (3,4.dihydroxyphenyl) (2,3,4-trihydroxyphenyl) methanoneand its derivaties. Arch Pharm (Weinheim) 2012;345:323-4.

21. Oyaizu M. Studies on product of browning reaction, antioxidative activities of product of browning reaction prepared from glucosamine. Jpn J Nutr 1986;44:307-15.

22. Nabavi SM, Ebrahimzedh MA, Navadi SF, Bahmaneslami MF. In vitro antioxidant and free radical scavenging activity of Diospyros lotus and Pyrus boissieriana growing in Iran. Pharm Mag 2009;4:122-6.

23. Nishikimi M, Rao NA, Yagi K. The occurance of superoxide anion in the reaction of reduced phenazine methosulfate and molecular oxygen. Biochem Biopsy Res Commun 1972;46:849-54.

24. Rasmussen JW, Martinez E, Louka P, Wingett DG. Zinc oxide nanoparticles for selective destruction of tumor cells and potential for drug delivery applications. Expert Opin Drug Deliv 2010;7:1063-77.
25. Xiong HM. $\mathrm{ZnO}$ nanoparticles applied to bioimaging and drug delivery. Adv Mater 2013;25:5329-35

26. Zhang ZY, Xiong HM. Photoluminescent $\mathrm{ZnO}$ nanoparticles and their biological applications. Materials 2015;8:3101-27.

27. Shi LE, Li ZH, Zheng W, Zhao YF, Jin YF, Tang ZX, et al. Synthesis, antibacterial activity, antibacterial mechanism and food applications of znO nanoparticles: A review. Food Addit Contam Part A Chem Anal Control Expo Risk Assess 2014;31:173-86.

28. Jiang Y, Zhang L, Wen D, Ding Y. Role of physical and chemical interactions in the antibacterial behavior of $\mathrm{znO}$ nanoparticles against E. Coli. Mater Sci Eng C Mater Biol Appl 2016;69:1361-6.

29. Dutta RK, Nenavathu BP, Gangishetty MK, Reddy AV. Antibacterial effect of chronic exposure of low concentration znO nanoparticles on E. Coli. J Environ Sci Health A Tox Hazard Subst Environ Eng 2013;48:871-8.

30. Ghannoum MA, Rice LB. Antifungal agents: Mode of action, mechanism of resistance, and correlation of these mechanisms with bacterial resistance. Clin Microbiol Rev 1999;12:501-17.

31. Nucci M, Marr KA. Emerging fungal diseases. Clin Infect Dis 2005;41:521-6.

32. Newman DJ, Cragg CM. Natural products as sources of new drugs over the last 25 years. J Nat Prod 2007;70:461-77.

33. Bhakya S, Muthukrishnan S, Sukumaran M, Muthukumar M. Biogenic synthesis of silver nanoparticles and their antioxidant and antibacterial activity. Appl Nanosci 2015;10:1-12.

34. Contreras-Guzman ES, Strong FC. Determination of tocopherols (Vitamin E) by reduction of cupricion. J AOAC Int 1982;65:1215-7.

35. Huang D, Ou B, Prior RL. The chemistry behind antioxidant capacity assays. J Agric Food Chem 2005;53:1841-56

36. Schaffazick SR, Pohlmann AR, de Cordova CA, Creczynski-Pasa TB, Guterres SS. Protective properties of melatonin-loaded nanoparticles against lipid peroxidation. Int J Pharm 2005;289:209-13.

37. Hema H. Hypoglycemic, hypolipidemic and antioxidant properties of combination of curcumin from Curcuma longa Linn and partially purified product from Abromaugusta Linn in streptozotocin induced diabetes. Indian J Clin Biochem 2002;17:33-43.

38. Halliwel B, Gutteridge JMC. Free Radicals in Biology and Medicine. New York: Oxford University Press; 1999.

39. Yen GC, Duh PC, Tsai CL. Relationship between antioxidant activity and maturity of peanut hulls. J Agric Food Chem 1993;41:67-70.

40. Taylor BS, Kim YM, Wang Q, Shapiro RA, Billiar TR, Geller DA, et al. Nitric oxide down-regulates hepatocyte-inducible nitric oxide synthase gene expression. Arch Surg 1997;132:1177-83.

41. Robak J, Gryglewsk RJ. Flavonoids are scavenger of superoxide anions. Bio Chem Pharm 1988;37:837-41. 